\title{
EFFECT OF FERMENTED CHUB MACKEREL EXTRACT ON LIPID METABOLISM OF DIABETIC RATS
}

\author{
U. Santoso ${ }^{1}$, S. Ishikawa ${ }^{2}$ and K. Tanaka ${ }^{2}$ \\ ${ }^{1}$ Faculty of Agriculture, Bengkulu University, Bengkulu - Indonesia. \\ ${ }^{2}$ Division of Bioresources and Bioproduction, Graduate School of Agriculture, \\ Hokkaido University, Sapporo 060-0809 - Japan \\ Corresponding E-mail: santosoburgo60@yahoo.com
}

Received January 26, 2010; Accepted July 28, 2010

\begin{abstract}
The present study was conducted to evaluate the effect of fermented chub mackerel extract (FCME) on lipid metabolism in diabetic rats. Four week-old male Wistar rats were divided into three groups based on weight. All rats were induced with diabetes mellitus by single intraperitoneal injection of streptozotocin at $45 \mathrm{mg} / \mathrm{kg}$ body weight. Thereafter, they were randomly distributed to three treatments with 7 rats assigned to each treatment. One group was the control with no additive, and twotreatment groups were given the purified diets supplemented with 1\% or 2\% FCME. Experimental results showed that in comparison to the control, diabetic rats fed FCME increased feed intake $(\mathrm{P}<0.01)$ and body weight gain $(\mathrm{P}<0.05)$. FCME inclusion significantly reduced the activities of acetyl-CoA carboxylase $(\mathrm{P}<0.01)$ and fatty acid synthetase $(\mathrm{P}<0.05)$ in diabetic rats. FCME significantly increased cholesterol $7 \alpha$-hydroxylase with no effect on HMG-CoA reductase activity. FCME had no effect on hepatic triglyceride, free cholesterol and phospholipid. FCME inclusion at $1 \%$ level significantly reduced serum triglyceride. FCME significantly increased HDL-cholesterol $(\mathrm{P}<0.05)$ with no effect on LDL + VLDL-cholesterol, and significantly reduced atherogenic index. FCME did not significantly affect serum insulin and glucose concentration. In conclusion, FCME supplementation altered lipid metabolism in diabetic rats. FCME supplementation reduced the risk of atherosclerosis in diabetic rats.

Keywords: fermented chub mackerel extract, lipid metabolism, diabetic rat
\end{abstract}

\section{INTRODUCTION}

Diabetic mellitus is a state of nutritional state of nutritional starvation which frequently results in severe metabolic imbalance and pathological change in many tissues (Inui et al., 2000). In relation to lipid metabolism, diabetic condition is characterized by increases both fatty acid and cortisol. Consequently this could account for why VLDL secretion is increased in ketotic type I diabetes, which is caused by insulin deficiency (Brindley, 1991). Hypersecretion of VLDL cause hypertriglyceridemia. Other dyslipidemia includes low HDL-cholesterol, and small, dense LDL. The incidence of atherosclerosis is 3-4 times greater in diabetics than non-diabetics at comparable plasma total cholesterol. Beyond total cholesterol concentration, lipid abnormalities in the plasma of diabetics include elevated triglyceride, decrease HDL-c levels, and the presence of small dense LDL. Dixon et al. (2002) found that the diabetic swine had a higher and broader IDL/LDL peak and a significant higher LDL/HDL-c ratio. Furthermore, they stated that the difference in lipoprotein profile per se may be the cause of increased atherosclerosis in diabetic swines. In addition, the lack of insulin action combined with the effect of glucocorticoids also the LDL receptor in the liver (Schneider, 1991) resulting lower removing the major proportion of IDL and LDL from the circulation leading to hypercholesterolemia. Duchateau et al. (2000) found that there was significantly increases in plasma apo L level, cholesterol and triglyceride in subjects with type II diabetes.

Some investigations have been conducted to lower obesity in diabetic animals. Dixon et al. (2002) found that atorvastatin $(80 \mathrm{mg} /$ day $)$ inclusion protected diabetic swine against coronary artery atherosclerosis. This protection was in part caused by reduced plasma triglyceride concentration since other lipid parameters, inclusing the LDL/HDL ratio had not been affected. Georgopoulos et al. (1998) found that a 
high monounsaturated fatty-acid enriched diet is not preferable to a high-carbohydrate diet in patients with type 1 Diabetes mellitus with regard to the occurrence of postprandial lipemia. Higashi et al. (2002) found that oleic acid enriched diet was associated with increased formation of postprandial chylomicron remnants compared with the linoleic acid enriched diet in patients with type 2 Diabetes mellitus. We recently found that fermented chub mackerel extract was effective to reduce lipid profiles in growing chicks (Tanaka et al., 1990), broiler chicks (Tanaka et al., 1992) and rats (Santoso et al., 2000; 2001). This FCME was known to be rich in peptides. Peptides were known to promote cholesterol efflux from cholesterol-enriched cells, activate the plasma LCAT and to protect against atherosclerosis (Garber et al., 2001). Therefore, it was assumed that FCME inclusion to the diet would reduce lipid profiles in diabetic animals. Therefore, the present study was conducted to evaluate effect of FCME on lipid metabolism in diabetic rats.

\section{MATERIALS AND METHODS}

Twenty one of four week-old male Wistar rats (body weight $110 \pm 10 \mathrm{~g}$ ) used in this experiment were purchased from Japan SLC Inc (Hamamatsu, Shizuoka, Japan). They were then weighed individually and divided into three groups based on weight. All rats were induced with diabetes mellitus by single intraperitoneal injection of streptozotocin at $45 \mathrm{mg} / \mathrm{kg}$ body weight \{2-deoxy-2 [([methylnitrosoamino] carbonyl)amino]-D-glucopyranose (given Sigma) at $0.1 \mathrm{M}$ citrate buffer solution, $\mathrm{pH} 4.5\}$. Thereafter, they were randomly distributed to three treatments with 7 rats assigned to each treatment. One group was the control with no additive, and two-treatment groups were given the purified diets supplemented with $1 \%$ or $2 \%$ FCME. The rats were raised to 7 weeks of age in individual cages in an air-conditional room (temperature $22 \pm 2^{\circ} \mathrm{C}$ with humidity 50 to $60 \%$ ) with the light on from 08:00 to 20:00. Rats were fed a commercial nonpurified diet (type CE-2, Japan Clea) for a week before the initiation of the experiment with purified diets. The composition of experimental diets is shown in Table 1. Feed and water were provided for ad libitum consumption. To confirm the induction of diabetes mellitus, the serum glucose level in the fasting state (16-hours starvation) was determined by using a commercial kit (Glucose CII-Test Wako kit).

Commercial FCME was obtained from Kanzaki Company, Ltd., Takamatsu, Japan. The main constituents of this extract are peptides with 20-50 chain-length amino acids. This product contains $39,6 \%$ moisture, $51.1 \%$ crude protein, $0.0 \%$ crude fat, $0.0 \%$ crude fiber, $8.7 \%$ crude ash and $0.6 \%$ nitrogen free extract (NFE). Amino acid profiles of FCME are published elsewhere (Santoso et al., 2000a).

Blood samples were drawn from tail arterial under ether narcosis before and every weeks after given streptozotocin, and left in an ice water to prevent glucose degradation. The serum was separated from each blood sample by centrifugation. Simultaneously glucose excretion to urine confirmed by test paper (Testepe, Shionogi Seiyaku Co., LTD).

At the end of experimental period, all rats were weighed individually. Thereafter, blood samples were drawn from heart and removed the liver under ether narcosis. The serum stored at $-30^{\circ} \mathrm{C}$ until the determination of glucose, insulin, total cholesterol, HDL-cholesterol and lipid fractions.

Enzyme assay was prepared as previously described (Santoso et al., 1995). The activities of key enzymes in fatty acid synthesis and cholesterogenesis were measured. AcetylCoenzyme A carboxylase (E.C. 6.2.1.3) activity was assayed by $\mathrm{H}^{14} \mathrm{CO}_{3}$-fixation method (Qureshi et al., 1980). Fatty acid synthetase (FAS) activity was assayed by the $1-{ }^{14} \mathrm{C}$-acetyl-CoA incorporation method (HSU et al., 1965). The 3hydroxy-3-methylglutaryl-CoA reductase activity was assayed by the method of Shefer et al. (1973). The protein content of the solution used for enzyme assay was determined by the method of Lowry et al. (1951) using bovine serum albumin as the standard. ACC and FAS activities were expressed as nanomole of substrate converted to product per minute per milligram of protein at $37^{\circ} \mathrm{C}$. 3-hydroxy-3-methylglutaryl-CoA reductase activity was expressed as picomole of substrate converted to product per minute per $\mathrm{mg}$ protein at $38^{\circ} \mathrm{C}$. Cholesterol $7 \alpha$-hydroxylase was expressed as nmol/hour/mg protein. Samples were analyzed in triplicate.

The lipid fractions were separated by thinlayer chromatography on silica gel chromarod using hexane-diethylether-formic acid (60:10:1) and hexane-benzene (1:1) as developing solvent and quantified by IATROSCAN TH-10 TLC/FID Analyzer (Iatron Laboratories, Inc., Tokyo, 
Table 1. Composition of Experimental Diet (\%)

\begin{tabular}{lccc}
\hline \multicolumn{1}{c}{ Ingredients } & O\% FCME & 1\% FCME & 2\% FCME \\
\hline Corn strach & 45 & 45 & 45 \\
Sucrose & 23.9 & 23.9 & 23.9 \\
Soybean Oil & 3 & 3 & 3 \\
Casein & 23 & 22 & 21 \\
Mackerel extract $_{\text {Mineral mixture }}^{1}$ & 0 & 1 & 2 \\
Vitamin A \& D mixture $^{2}$ & 4 & 4 & 4 \\
Vitamin B mixture $^{3}$ & 0.1 & 0.1 & 0.1 \\
Total & 1 & 1 & 1 \\
Chemical Composition $_{\text {Protein (\%) }}$ & 100 & 100 & 100 \\
ME (kcal/kg) & 23 & 22.4 & 21.8 \\
ME-protein ratio & 3751.6 & 3733.6 & 3715.6 \\
\hline
\end{tabular}

1) Supplied 650.0 g CaHPO4, $160.0 \mathrm{~g} \mathrm{NaCl}, 140.0 \mathrm{~g} \mathrm{K2CO} 3,32.7 \mathrm{~g} \mathrm{MgCO} 3,10.0 \mathrm{~g} \mathrm{FeSO} 4.7 \mathrm{H} 2 \mathrm{O}$,

$3.0 \mathrm{~g} \mathrm{MnSO} 4 . \mathrm{H} 2 \mathrm{O}, 1.0 \mathrm{~g} \mathrm{CoCl} 2.6 \mathrm{H} 2 \mathrm{O}, 1.0 \mathrm{~g} \mathrm{CuSO} 4,2.0 \mathrm{~g} \mathrm{ZnCO} 3,0.1 \mathrm{~g} \mathrm{KI}$ and $0.2 \mathrm{~g} \mathrm{NaF}$ per $1 \mathrm{~kg}$. mixture

2) Supplied $0.10 \mathrm{~g}$ retinyl acetate, $0.00005 \mathrm{~g}$ cholecalciferol and $0.8995 \mathrm{~g}$ corn starch per $1 \mathrm{gram}$ mixture.

3) Supplied $0.083 \mathrm{~g}$ thiamine- $\mathrm{HCl}, 0.233 \mathrm{~g}$ riboflavine, $0.833 \mathrm{~g}$ niacin, $0.75 \mathrm{~g}$ Ca-pantothenate, $0.1 \mathrm{~g}$ pyridoxine- $\mathrm{HCl}, 0.058 \mathrm{~g}$ folic acid, $15 \mathrm{~g}$ inositol, $1.667 \mathrm{~g} \mathrm{p}$-aminobenzoic acid, $0.005 \mathrm{~g}$ biotin, $0.004 \mathrm{~g}$ cyanocobalamin, $33.333 \mathrm{~g}$ choline- $\mathrm{HCl}, 0.333 \mathrm{~g}$ menadione and $47.599 \mathrm{corn}$ strach per $100 \mathrm{~g}$ mixture.

Japan).

Concentrations of serum total cholesterol, HDL-cholesterol were measured with commercial kits (Cholesterol E Test Wako Kit and HDLcholesterol E Test Wako Kit from Wako Junyaku Kogyo Co. LTD). The difference between the total cholesterol and HDL-cholesterol was assumed to be LDL+VLDL cholesterol (Nishizawa and Fudamoto, 1995). An atherogenic index was measured using equation published by Nishizawa and Fudamoto (1995).

Treatment effects were assessed for all response variables using one-way ANOVA in which the overall treatment differences were represented by single orthogonal contrasts between control and treatment groups (Shinjo, 1990).

\section{RESULTS}

FCME inclusion significantly increased feed intake $(\mathrm{P}<0.01)$ and body weight gain $(\mathrm{P}<0.05)$ FCME had no effect on liver weight (Table 2). FCME inclusion did not influence the concentration of serum glucose (Table 3 ).

The activities of acetyl-CoA carboxylase and fatty acid synthetase were significantly lower in diabetic rats fed FCME, whereas cholesterol $7 \alpha$ -hydroxylase was significantly increased $(\mathrm{P}<0.01)$. The activity of HMG-CoA reductase was not significantly affected (Table 4).

FCME had no effect on hepatic triglyceride, free cholesterol and phospholipid. Serum triglyceride was significantly lower in rats fed diet with FCME $(\mathrm{P}<0.01)$, but total cholesterol and free cholesterol were not significantly influenced. Serum HDL-cholesterol was significantly increased $(\mathrm{P}<0.05)$ with lower atherogenic index $(\mathrm{P}<0.05)$. Mackerel extract had no effect on LDL+VLDL-cholesterol concentration (Table 5). Dietary FCME had no effect on serum insulin. However, 2\% FCME inclusion tended to increase insulin concentration at $24.4 \%$ level.

\section{DISCUSSION}

An increase in body weight gain resulted from higher feed intake in FCME group. It is possible that streptozotocin eliminated the advantage of FCME in improving feed conversion ratio. It is unkown why feed intake of diabetic rats fed FCME was higher. Although, there is 
Table 2. Effects of Fermented Chub Mackerel Extract on Feed Intake, Body Weight Gain and Feed Conversion Ratio of Diabetic Rats

\begin{tabular}{lccc}
\hline \multicolumn{1}{c}{ Variables } & $0 \%$ FCME & $1 \%$ FCME & $2 \%$ FCME \\
\hline Final body weight, g/rat & $194.28 \pm 6.2^{1}$ & $209.12 \pm 5.6$ & $218.92 \pm 5.4$ \\
Body w eight gain, g/day & $3.01 \pm 0.60$ & $3.54 \pm 0.65 *$ & $3.89 \pm 0.59^{*}$ \\
Feed intake, g/day & $17.80 \pm 1.2$ & $23.80 \pm 1.8 * * *$ & $24.60 \pm 2.2 * *$ \\
Feed conversion ratio & $5.91 \pm 0.05$ & $6.72 \pm 0.06$ & $6.32 \pm 0.05$ \\
Liver weight, g/100 g BW & $4.78 \pm 0.43$ & $4.87 \pm 0.21$ & $4.82 \pm 0.31$ \\
\hline Mean \pm SD for 7 rats & & \\
$*$ Significantly different $(\mathrm{P}<0.05)$ from the control group. & \\
** Significantly different $(\mathrm{P}<0.01)$ from the control group. & \\
$* * *$ Significantly different $(\mathrm{P}<0.001)$ from the control group.
\end{tabular}

Table 3. Effects of Fermented Chub Mackerel Extract on Concentration of Glucose in the Serum of Diabetic Rat

\begin{tabular}{cccc}
\hline $\begin{array}{c}\text { Weeks } \\
\text { after admi- } \\
\text { nistration }\end{array}$ & $0 \%$ FCME & $1 \%$ FCME & $2 \%$ FCME \\
\hline 0 & $148.9 \pm 11.5^{1}$ & $148.9 \pm 11.5$ & $148.9 \pm 11.5$ \\
1 & $347.6 \pm 29.6$ & $364.8 \pm 35.0$ & $318.9 \pm 53.3$ \\
2 & $468.1 \pm 28.9$ & $514.3 \pm 29.4$ & $462.2 \pm 68.7$ \\
3 & $475.1 \pm 23.5$ & $461.5 \pm 25.0$ & $448.2 \pm 37.2$ \\
4 & $554.2 \pm 82.9$ & $536.0 \pm 41.6$ & $520.8 \pm 29.4$ \\
\hline
\end{tabular}

Mean \pm SD for 7 rats

correlation between serum glucose and feed intake $(\mathrm{r}=-0.93)$, it appear that the higher feed intake could not fully be explained by lower serum glucose concentration. It was known that FCME rich in glutamic acid, one of an active taste compounds in feed that may also improve the palatability of diet, and therefore it increased feed intake. As far as growth efficiency concerned, the inclusion of FCME in diabetic rats had no beneficial effect. The present results agree with the observation of Santoso et al. (2000) who found that FCME inclusion had a little value on improving feed efficiency in rats fed cholesterolcontaining diet.

Acetyl-CoA carboxylase was suggested as a rate limiting enzyme in fatty acid synthesis (Brindley, 1991). Therefore, the reduction of acetyl-CoA carboxylase activity in diabetic rats fed FCME would result in lower fatty acid synthesis. Our previous studies (Santoso et al., 2000, 2001) also found that FCME inclusion resulted in lower acetyl-CoA carboxylase and fatty acid synthetase activities of rats fed diet without cholesterol or those fed high-cholesterol containing diet. A reduced in hepatic fatty acid synthesis is a major factor which caused lower hepatic triglyceride synthesis (Scorve et al., 1993), and resulting in lower triglyceride secretion into circulation. This may explain lower serum triglyceride in diabetic rats fed 1\% FCME. It is unkown however, although feeding $2 \%$ FCME reduced hepatic acetyl-CoA carboxylase and fatty acid synthetase activities it resulted in higher serum triglyceride concentration and no change in hepatic triglyceride. It was known that a major site of fatty acid synthesis in rats was in adipose tissues. Therefore, it is needed to evaluate the activity of acetyl-CoA carboxylase and fatty acid synthetase in adipose tissue to elucidate the mechanism of different change in serum triglyceride. In addition, triglyceride clearance from the circulation by lipoprotein lipase may also contribute to this phenomenon.

A major advance in the understanding of cholesterol metabolism emerged from the observation that in rats the liver exhibits high rates of cholesterol synthesis whereas nonhepatic tissues other than intestine show rates that are less than 5\% of those in the liver (Balasubramaman et al., 1976). FCME inclusion did not reduce the activity of hepatic HMG-CoA reductase, a rate limiting enzyme in cholesterol synthesis. Therefore, FCME inclusion might have no effect on hepatic cholesterol synthesis. However, FCME inclusion might increase hepatic bile acid synthesis as indicated by higher activity of hepatic cholesterol $7 \alpha$-hydroxylase activity, a rate limiting enzyme in bile acid synthesis. An increase in hepatic bile acid synthesis, however, 
Table 4. Effects of Fermented Chub Mackerel Extract on Activities of Lipogenic Related Enzymes in the Liver of Diabetic Rats

\begin{tabular}{lccc}
\hline \multicolumn{1}{c}{ Enzymes } & 0\% FCME & $1 \%$ FCME & $2 \%$ FCME \\
\hline Acetyl-CoA carboxylase (nmol/min/mg protein & $1.61 \pm 0.511$ & $1.08 \pm 0.23 * *$ & $1.07 \pm 0.58^{*}$ \\
Fatty acid synthetase (nmol/min/mg protein & $1.15 \pm 0.44$ & $0.71 \pm 0.29 *$ & $0.69 \pm 0.45^{*}$ \\
HMG-CoA reductase (pmol/min/mg protein & $13.72 \pm 4.25$ & $11.76 \pm 2.08$ & $12.64 \pm 3.05$ \\
Choles terol 7-hydroxylase (nmol/hr/mg protein & $10.07 \pm 1.23$ & $11.69 \pm 0.65^{* *}$ & $17.09 \pm 4.29 * *$ \\
\hline
\end{tabular}

${ }^{1}$ Mean \pm SD for 7 rats; *Significantly different $(\mathrm{p}<0.05)$ from the control group.

** Significantly different $(\mathrm{p}<0.01)$ from the control group.

Table 5. Effects of Fermented Chub Mackerel Extract on Various Lipid Fractions and Insulin of Diabetic Rats

\begin{tabular}{lccc}
\hline \multicolumn{1}{c}{$\begin{array}{c}\text { Variables } \\
\text { Liver }(\mathrm{mg} / \mathrm{g})\end{array}$} & $0 \%$ FCME & $1 \%$ FCME & $2 \%$ FCME \\
\hline Triglyceride & $4.3 \pm 1.0^{1}$ & $3.8 \pm 1.5$ & $3.6 \pm 0.8$ \\
Free cholesterol & $1.7 \pm 0.1$ & $1.9 \pm 0.2$ & $1.9 \pm 0.2$ \\
Phospholipid & $41.1 \pm 7.8$ & $42.2 \pm 7.0$ & $37.1 \pm 3.4$ \\
Serum (mg/100 ml) & & & \\
Total cholesterol & $90.7 \pm 16.6$ & $98.6 \pm 12.8$ & $98.0 \pm 12.3$ \\
Free cholesterol & $19.9 \pm 5.0$ & $18.4 \pm 2.6$ & $18.1 \pm 1.8$ \\
HDL-cholesterol & $59.4 \pm 14.6$ & $72.9 \pm 6.9^{*}$ & $72.7 \pm 5.3 *$ \\
LDL+VLDL- & $31.1 \pm 5.1$ & $25.7 \pm 2.5$ & $25.2 \pm 3.5$ \\
cholesterol & & & \\
Triglyceride & $86.8 \pm 19.2$ & $53.0 \pm 14.5 *$ & $81.4 \pm 17.8$ \\
Phospholipid & $224.8 \pm 35.1$ & $212.3 \pm 17.9$ & $222.4 \pm 25.6$ \\
Atherogenix index & $0.50 \pm 0.10$ & $0.35 \pm 0.05 * *$ & $0.39 \pm 0.07 *$ \\
Insulin $(\mu \mathrm{U} / \mathrm{ml})$ & $16.0 \pm 6.7$ & $15.2 \pm 7.5$ & $19.9 \pm 14.9$ \\
\hline
\end{tabular}

${ }^{1}$ Mean+SD for 7 rats

${ }^{2}$ (Total cholesterol - HDL-cholesterol)/HDL-cholesterol *Significantly different $(\mathrm{p}<0.05)$ from the control group

** Significantly different $(\mathrm{p}<0.01)$ from the control group

was not accompanied by neither lower hepatic cholesterol nor serum total cholesterol. No change in hepatic or serum cholesterol in rats fed FCME was in agreement with the observation of Santoso et al. (2001).

A protective effect against the development of atherosclerotic disease is attributed to HDLcholesterol on the basis of their key roles in reverse cholesterol transport and also their antioxidant properties. Badimon et al. (1990) also found that injection of HDL into rabbits fed on atherogenic diet has been shown to inhibit atherosclerotic lesion formation. Therefore, an increase in HDL-cholesterol with tendency of lower LDL-cholesterol by FCME in the present study might have beneficial impact on reducing the risk of atherosclerosis. In our previous results (Santoso et al., 2000) also showed that when FCME was supplemented to a high-cholesterol containing diet, an increase in serum HDLcholesterol with lower LDL-cholesterol without any change in total cholesterol was observed. Lower atherogenic index found in rats fed FCME indicated that FCME inclusion might reduce the risk of atherosclerosis in diabetic rats.

FCME had no antidiabetic properties as indicated by no effect of FCME on serum glucose and insulin.

\section{CONCLUSION}

As far as growth efficiency concerned, the inclusion of FCME in diabetic rats had no beneficial effect. FCME supplementation reduced the activities of hepatic acetyl-CoA carboxylase and fatty acid synthetase, but it increased the activity of hepatic cholesterol $7 \alpha$-hydroxylase in diabetic rats. FCME supplementation reduced the risk of atherosclerosis as indicated by lower atherogenic index.

\section{REFERENCES}

Badimon, J. J., L. Badimon and V. Fuster. 1990. Regression of aherosclerotic lesions by high density lipoprotein plasma fraction in the cholesterol-fed rabbit. J. Clin. Invest., 85:1234-1241.

Balasubramanian, S., J. L. Goldstein, J. R. Faust and M. S. Brown. 1976. Evidence for regulation of 3-hydroxy-3-methylglutaryl coenzyme A reductase activity and cholesterol synthesis in nonhepatic tissues of rat. Proc. Natl. Acad. Sci. 73:2564-2568. 
Brindley, D. N. 1991. Metabolism of triacylglycerols. In: Biochemistry of Lipids, Lipoproteins and Membranes (Vance, D. E. and J. Vance ed.). pp. 171-203.

Dixon, J. L., S. Shen, J. P. Vuchetich, E. Wysocka, G. Y. Sun and M. Sturek. 2002. Increased aherosclerosis in diabetic dyslipidemic swine protection by atorvastatin involves decreased VLDL triglycerides but minimal effects on the lipoprotein profile. J. Lipid Res. 43:1618-1629.

Duchateau, P. N., I. Movsesyan, S. Yamashita, N. Sakai, K. Hirano, S. A. Schoenhaus, P. M. O'connor-Kearns, S. J. Spencer, R. B. Jafte, R. F. Redberg, B. Y. Ishida, Y. Matsuzawa, J. P. Kane and M. J. Malloy. 2000. Plasma apolipoprotein L concentrations correlate with plasma triglyceride and cholesterol levels in normolipidemic, hyperlipidemic and diabetic subjects. J. Lipid Res. 41:1231-1236.

Garber, D. W., G. Datta, M. Chaddha, M. N. Palgunachari, S. Y. Hama, M. Navab, A. M. Fogelman, J. P. Segrest and G. M. Anantharamaiah. 2001. A new synthetic class A amphipathic peptide analogue protects mice from diet-induced atherosclerosis. J. Lipid Res. 42:545-552.

Georgopoulos, A., J. P. Bantle, M. Noutson, W. R. Swaim and S. J. Parker. 1998. Differences in the metabolism of postprandial lipoproteins after a high-monounsaturated-fat vs a highcarbohydrate diet in patients with type 1 diabetes mellitus. Arteriocler. Thromb. Vasc. Biol. 18:773-782.

Higashi, K., M. Shige, T. Ito, K. Nakajima, T. Ishikawa, H. Nakamura and F. Ohsuzu. 2002. Effect of a low-fat diet enriched with oleic acid on postprandial lipemia in patients with type 2 diabetes mellitus. Lipids 36: 1-6.

Hsu, R. Y., G. Wasson and J. W. Porter. 1965. The purification and properties of the fatty acid synthetase of pigeon liver. J. Biol. Chem. 240: 3736-3746.

Inui, H., R. Yasuno, M. Takenoshita, Y. Ohnishi, M. Sakamoto, J. Matsuzaki, R. Yamaji, K. Miyatake, A. Yamatodani and Y. Nakano. 2000. Increases in gastric histidine decarboxylase activity and plasma gastrin level in streptozotocin-induced type 1 diabetic rats. J. Nutr. Sci. Vitaminol. 46:144148.

Kannel, W. B.,and D. L. Mcgee. 1979. Diabetes and cardiovascular disease: The Framingham study. J. Am. Med. Assoc., 241:2035-2038.
Lowry, O. H., N. J. Rosebrough, A. L. Fart and R. J. Randell. 1951. Protein measurement with folin phenol reagent. J. Biol. Chem. 193:265275.

Mattson, F. H. and S. M. Grundy. 1985. Comparison of effects of dietary saturated, monounsaturated and polyunsaturated fatty acid on plasma lipids and lipoproteins in man. J. Lipid Res. 26: 194-202.

Miller, G. S., and N. F. Miller. 1975. Plasma high density lipoprotein and development of ischemic heart disease. Lancet 1:16-19.

Nishizawa, N. and Y. Fudamoto. 1995. The evelation of plasma concentration of highdensity lipoprotein cholesterol in mice fed with protein from proso millet. Biosci. Biotech. Biochem. 59: 333-335.

Qureshi, A. A., W. C. Burger, N. Prentice, H. R. Bird and M. L. Sunde. 1980. Regulation of lipid metabolism in chicken liver by dietary cereals. J. Nutr. 110:388-393.

Santoso, U., M. Ishikawa and K. Tanaka. 2000. Effects of fermented chub mackerel extract on lipid metabolism of rats fed a highcholesterol diet. Asian-Aust. J. Anim. Sci. 13: 516-520.

Santoso, U., S. Ishikawa and K. Tanaka. 2001. Effect of fermented chub mackerel extract on lipid metabolism of rats fed diet without cholesterol. Asian-Aust. J. Anim. Sci. 14: 535-539.

Schneider, W. J. 1991. Removal of lipoproteins from plasma. In: Biochemistry of Lipids, Lipoproteins and Membranes (Vance, D. E. and J. Vance ed.). pp. 461-487.

Shefer, S., S. Hauser, L. Lapar and E. H. Mosbch. 1973. Regulatory effects of dietary sterols and bile acids on rat intestinal 3-hydroxy-3methylglutaryl-CoA reductase. J. Lipid Res. 14:400-405.

Shinjo, A. 1990. First Course in Statistics. Laboratory of Animal Breeding, College of Agriculture, University of the Ryukyus. Japan.

Spady, D. K. and J. M. Dietschy. 1985. Dietary saturated triacylglycerols suppress hepatic low-density lipoprotein transport in hamster. J. Clin. Invest. 81:300-309.

Tanaka, K., B. S. Youn, S. Ohtani and M. Sakaida. 1990. Effects of fermented product from chub mackerel on growth, and on lipogenesis and contents of various lipids in the liver of growing chicks. Jpn. J. Zootech. Sci. 61:1102-1106. 
Tanaka, K., B. S. Youn, U. Santoso, S. Ohtani and M. Sakaida. 1992. Effects of fermented products from chub mackerel extract on growth, and carcass composition, hepatic lipogenesis and on contents of various lipid fractions in the liver and the thigh muscle of broilers. Anim. Sci. Technol. 63:32-37.

Vega, G. L., F. Grosjek, R. Wolf and S. M. Grundy. 1962. Influence of polyunsaturated fats on composition of plasma lipoproteins and apolipoproteins. J. Lipid Res. 23:811-822 